\title{
Influenza infections during pregnancy in the mouse
}

\author{
BY K. WILLIAMS AND J. S. MACKENZIE* \\ University Department of Microbiology, Perth Medical Centre, \\ Nedlands, Western Australia 6009
}

(Received 15 February 1977)

\begin{abstract}
SUMMARY
The effect of a sublethal dose (0.5 LD 50) of influenza A/WSN (H0N1) administered intranasally in the 1st and 3rd weeks of pregnancy was studied in $\mathrm{C} 3 \mathrm{H}$ inbred mice. Maternal and neonatal mortality rates were significantly increased by infections in the 3rd week of pregnancy, but not in the 1st week. Infections during the last part of the 1st week significantly depressed the growth rate of neonates. No evidence of viraemia, transplacental transmission or congenital malformations were observed from infections during either week. The results are discussed in terms of a possible model for human influenza infections during pregnancy to determine the potential risks to the mother, fetus and neonate.
\end{abstract}

\section{INTRODUCTION}

Influenza A virus infections in women during the 1st trimester of pregnancy have been associated with congenital malformations and stillbirths without malformation and, during the 2nd or 3rd trimesters, have been associated with abortion and an increased incidence of maternal mortality (reviewed by Mackenzie \& Houghton, 1974). Transplacental transmission has been reported in a fatal case of influenza during the 3rd trimester with virus being isolated from fetal tissues and amniotic fluid (Yawn et al. 1971).

Congenital malformations have also been produced in Swiss albino mice inoculated intranasally with sublethal doses of influenza A/PR8(H0N1), either before or 4 days after mating, and although no effect was observed on litter sizes, pregnancy rates were decreased (Adams et al. 1956). In a further study from the same laboratory, congenital malformations were not observed in mice inoculated with high lethal doses of PR8 virus by intranasal, intraperitoneal or intravenous routes during the 2nd and 3rd weeks†. Transplacental transmission occurred in the 3rd week after inoculation by all three routes, but not in mice inoculated with influenza A/NWS(H0N1) by the intracerebral route (Seim, Ly, Imagawa \& Adams, 1960).

This communication describes a preliminary study to find an animal model system in which to examine the risks that influenza virus infections during pregnancy might confer on both mother and fetus.

* Reprint requests should be addressed to Dr Mackenzie.

$\dagger$ Each week in mice is approximately equivalent to a trimester in human pregnancy. 


\section{MATERIALS AND METHODS}

Virus strain

Influenza $\mathrm{A} / \mathrm{WSN}(\mathrm{H} 0 \mathrm{~N} 1$ ) was used in all experiments. Virus stocks were prepared in 10- or 11-day-old embryonated chicken eggs. After $40 \mathrm{~h}$ incubation, infected allantoic fluids were removed, clarified by centrifugation at $800 \mathrm{~g}$, and stored at $-70^{\circ} \mathrm{C}$.

\section{Animals}

$\mathrm{C} 3 \mathrm{H} / \mathrm{HeJ}$ inbred mice were obtained from the Perth Medical Centre Animal Breeding Unit. Before mating, 12- to 16-week-old male mice were isolated in separate cages for a minimum of 3 days. Two 12-week-old virgin female mice were then placed into each cage, and examined every $12 \mathrm{~h}$ thereafter for the presence of vaginal plugs as an indication that mating had taken place. The length of the gestational period of $\mathrm{C} 3 \mathrm{H}$ mice was 20 days from the day of detection of a vaginal plug to the day of birth. Days 1-6, 7-13 and 14-20 post-conception were classified as 1 st, 2nd and 3rd weeks respectively. Male mice were routinely removed before virus inoculation.

\section{Mouse inoculation}

Lightly etherized mice were inoculated by the intranasal route with $25 \mu \mathrm{l}$ of virus diluted in PBS to give a dose of 0.5 LD 50. Control mice were inoculated similarly with PBS.

\section{Haemagglutination titrations}

Serial twofold dilutions of virus in citrate buffer $(0.85 \%$ sodium chloride, $2 \%$ sodium citrate) were made in disposable 'Microtitre' trays (Cooke Engineering Co., Virginia, U.S.A.), and a $0.5 \%$ suspension of chicken erythrocytes in citrate buffer was added to each well. After $35 \mathrm{~min}$ at $37^{\circ} \mathrm{C}$, the end point was read as the highest dilution of virus causing haemagglutination.

\section{Isolation of virus from fetuses}

Pregnant mice were inoculated intranasally with $0.5 \mathrm{LD} 50$ of virus at various stages during the 1st and 3rd weeks. On days 4 and 8 after inoculation the mice were killed by the intraperitoneal administration of $0.2 \mathrm{ml}$ Nembutal (Sodium pentabarbitone, $60 \mathrm{mg} / \mathrm{ml}$, Abbot Laboratories). The uterine horns were removed and the fetuses separated and rinsed in sterile PBS before grinding in a pre-chilled mortar. Offspring born from mice inoculated in the 3rd week were killed and the head, limbs and skin removed before grinding. Fetuses and unweaned young were ground in $3 \mathrm{ml}$ PBS, suspensions of three fetuses or two unweaned young pooled, and clarified by centrifugation at $800 \mathrm{~g}$ for $10 \mathrm{~min}$. Supernatants were inoculated into the allantoic cavities of 10-day-old embryonated chicken eggs. After 3 days incubation at $37{ }^{\circ} \mathrm{C}$, allantoic fluids were harvested and tested for the growth of virus by haemagglutination. 
Table 1. Maternal mortality in mice following influenza infection during the 1 st or 3 rd weeks of pregnancy

$\begin{array}{lccc}\text { Gravid state } & \begin{array}{c}\text { No. of } \\ \text { mice }\end{array} & \begin{array}{c}\text { No. of } \\ \text { deaths }\end{array} & \begin{array}{c}\text { Mortality } \\ (\%)\end{array} \\ \text { Non-pregnant } & 24 & 6 & 25 \\ \text { 1st week } & 64 & 17 & 26 \cdot 6 \\ \text { 3rd week } & 32 & 25 & 78 \cdot 1^{*}\end{array}$

* Significant, compared to non-pregnant mice, $\chi^{2}=15 \cdot 66, P<0.001$.

Blood collection for studies of viraemia

Blood was collected from the retro-orbital venous plexus in heparinized microcapillary tubes (Gelman-Hawksley Ltd, England), and inoculated into embryonated chicken eggs for virus isolation, as described above.

\section{RESULTS}

\section{Maternal mortality}

Pregnant mice were inoculated with 0.5 LD 50 of WSN intranasally during the 1st or 3rd weeks, and their mortality rates compared with non-pregnant control mice. The results are shown in Table 1. No differences in mortality rates were observed between pregnant mice inoculated during the 1st week and non-pregnant mice, but mice inoculated during the 3rd week were significantly more susceptible, with deaths occurring 6-9 days after infection $\left(\chi^{2}=15 \cdot 66, P<0 \cdot 001\right)$.

\section{Litter sizes, neonatal development and congenital malformations}

The sizes of litters born to mice inoculated with WSN at various days after conception during the 1st or 3rd weeks (excluding mothers dying from the infection) were not significantly different from litter sizes from control mice (Table 2). The neonates were examined periodically for 8 weeks after birth to determine the effect that influenza infections during pregnancy might have exerted on their subsequent development. The results are shown in terms of infant mortality (Table 2) and infant growth rates (Fig. 1).

Offspring from mothers inoculated with WSN during the 3rd week were found to have significantly decreased survival rates compared with offspring from control mice $\left(\chi^{2}=8.61, P<0.005\right)$, and a similar trend was observed in offspring from mice inoculated during the 1st week $(P \geqslant 0 \cdot 05)$ (Table 2).

Litters from mice inoculated with WSN, and those from control mice, were weighed individually at birth and on every 2nd day over the following 8 weeks. From the 4th to the 8th week it was evident that the growth rates of males and females differed considerably. To eliminate inaccuracies due to variations in the distribution of the sexes among litters, separate growth rates were calculated for males and females from the 4th week onwards. The growth rates of mice born to mothers inoculated on days 1-4 after conception, or to mothers inoculated during the 3 rd week, were not significantly different from mice born to uninfected control 
Table 2. Litter sizes and infant mortality in mice during the first 8 weeks of life after influenza infections in the 1st or 3 rd weeks

\begin{tabular}{|c|c|c|c|c|c|}
\hline Week & Group & $\begin{array}{l}\text { No. of } \\
\text { litters }\end{array}$ & $\begin{array}{c}\text { Mean } \\
\text { litter size } \\
\text { at birth }\end{array}$ & $\begin{array}{c}\text { No. of } \\
\text { young at } \\
\text { birth }\end{array}$ & $\begin{array}{l}\text { No. of } \\
\text { survivors } \\
\text { after } \\
\mathbf{8} \text { weeks }\end{array}$ \\
\hline 1 & $\begin{array}{l}\text { Virus-infected } \\
\text { Control }\end{array}$ & $\begin{array}{l}17 \\
21\end{array}$ & $\begin{array}{l}7 \cdot 53 \\
5 \cdot 9\end{array}$ & $\begin{array}{l}128 \\
124\end{array}$ & $\begin{array}{l}106^{*} \\
113^{*}\end{array}$ \\
\hline 3 & $\begin{array}{l}\text { Virus-infected } \\
\text { Control }\end{array}$ & $\begin{array}{l}7 \\
9\end{array}$ & $\begin{array}{l}6 \cdot 86 \\
5 \cdot 56\end{array}$ & $\begin{array}{l}48 \\
50\end{array}$ & $\begin{array}{l}30 \dagger \\
44 \dagger\end{array}$ \\
\hline
\end{tabular}

mothers (Fig. 1A). When inoculation was carried out on days 5, 6 and 7 after conception, however, the offspring were found to grow more slowly than those born to control mothers (Fig. 1B-D). This difference was particularly significant for the offspring of mothers inoculated on day 5 after conception (Fig. 1B).

No congenital anomalies of any description were observed from 57 mice inoculated during the 1st week. Of the 57 mice, 23 produced litters, 26 were killed 8 days after infection, and 8 died from the infection.

\section{Viraemia and transplacental transmission}

Two groups of 11 mice, which had received 0.5 LD 50 or 5 LD 50 of WSN respectively during the 1st or 3rd weeks, were bled from the retro-orbital sinus at 12-hourly intervals for 7 days after infection, and the heparinized whole blood passaged twice through the allantoic cavity of 11-day-old embryonated eggs for virus isolation. After 3 days incubation, the allantoic fluids were harvested and assayed for virus by haemagglutination. All blood samples were negative, and no evidence of viraemia could be detected.

Attempts were also made to isolate virus from fetal or infant tissues as evidence for transplacental transmission. Uterine horns were removed 4 or 8 days after infection from 51 mice inoculated during the 1st week $(7$ mice each day after conception) and a further 12 litters were examined which had been born to mice inoculated in the 3rd week. Fetal or infant tissue homogenates were passaged twice through the allantoic cavity of 11-day-old embryonated eggs, and allantoic fluids assayed by haemagglutination for the growth of virus. No evidence was obtained for the occurrence of transplacental transmission during either week.

\section{DISCUSSION}

The evidence linking influenza infections during the 1st trimester with malformations of the central nervous and circulatory systems in the human fetus has been contradictory, both for (Coffey \& Jessop, 1959; Hakosalo \& Saxen, 1971) and against (Leck, 1963, 1971; Leck, Hay, Witte \& Greene, 1969; Wilson \& Stein, 1969), although stronger evidence has been presented for an association with cleft lip and 

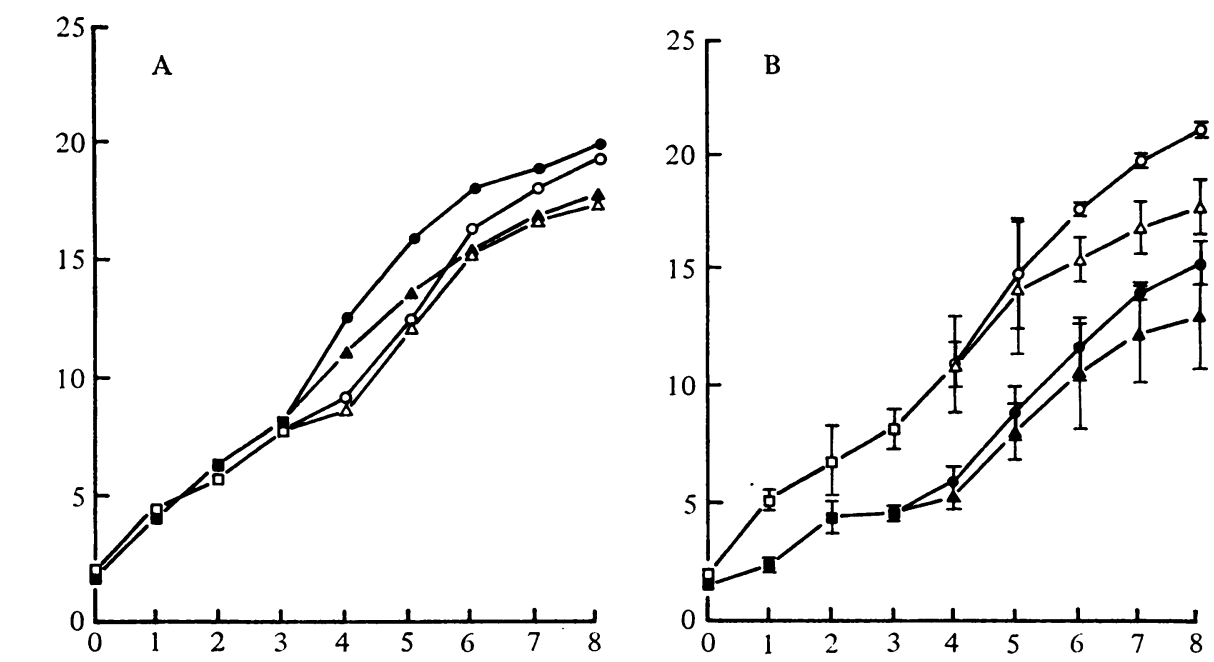

$\frac{E}{\sqrt{0}}$

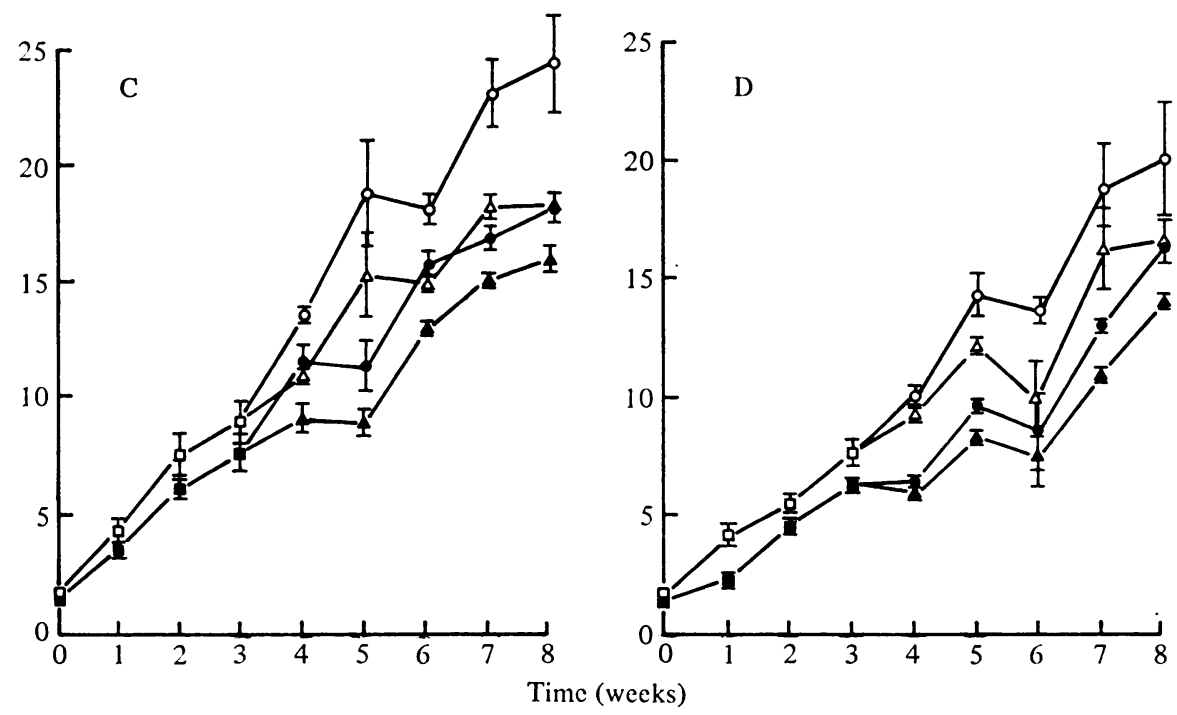

Fig. 1. The effect of maternal infection of mice with influenza on neonatal growth rates. Virus was administered intranasally on day $1(A)$, day $5(B)$, day $6(C)$ and day 7 (D) post-conception. Offspring from infected mothers, $\square-\square=$ males and females; $\boldsymbol{0}=$ males; $\boldsymbol{\Delta}-\boldsymbol{\Delta}=$ females. Offspring from uninfected control mothers, $\square-\square=$ males and females; $\bigcirc-O=$ males; $\Delta-\Delta=$ females. Each point represents the mean of 18 mice, and vertical bars enclose 1 standard deviation.

reductive deformities (Leck, 1963, 1971; Leck et al. 1969). Chick embryos and rhesus monkeys have been used in addition to mice for assessing the potential teratogenicity of influenza infections. Direct inoculation of early chick embryos through the vitelline membrane with A/NWS (H0N1) and A/PR 8 (H0N1) strains of influenza produced a number of malformations including microencephaly, axial 
flexion, retardation of the lens, and myeloschisis (Hamburger \& Habel, 1947; Heath et al. 1956; Robertson, Williamson \& Blattner, 1960). Hydrocephalus was observed in rhesus monkeys after direct inoculation of A/Aichi/2/68 (H3N2) into the brains of fetuses at the beginning of the 3rd trimester (London, Fuccillo, Sever $\&$ Kent, 1975). It should be noted, however, that in both animal systems virus was inoculated directly into embryonic or fetal tissues.

Sublethal doses of PR 8 administered intranasally to Swiss albino mice in the 1st week produced malformations of the central nervous system (Adams et al. 1956), but malformations were not observed with high lethal doses of the same virus administered by intranasal, intraperitoneal or intravenous routes during the 2nd or 3rd weeks (Seim et al. 1960). In the present study, malformations were not detected in the litters or fetuses of 57 mice inoculated during the 1st week or in 24 litters of mice inoculated in the 3rd week. However, both virus and mouse strains differed from those used by Adams et al. (1956).

For congenital malformations to be produced, the virus must either be able to cross the placenta following viraemia, or must cause fetal damage through an indirect method such as toxaemia or by metabolites from damaged cells. Viraemia has been reported in severe human influenza infections (Naficy, 1963; Lehmann \& Gust, 1971; Khakpour, Saidi \& Naficy, 1969), but only a single case of transplacental transmission has been recorded (Yawn et al. 1971). This occurred in a fatal case of influenza during the 3rd trimester. Transplacental transmission has also been observed in the ferret after intracardial inoculation (Sweet, Toms, Kingsman \& Smith, 1976). Viraemia has been reported in mice after aerosol infection with PR 8 virus (Hamre, Appel \& Loosli, 1955), and transplacental transmission has been observed in Swiss albino mice inoculated with PR 8 by the intranasal, intraperitoneal and intravenous routes, but only during the 3rd week despite attempts to isolate virus from fetuses earlier in pregnancy (Seim et al. 1960). In this study viraemia could not be detected from $12 \mathrm{~h}$ to 7 days after infection in 22 mice inoculated during the 1 st or 3 rd weeks, nor was evidence obtained for transplacental transmission in 51 mice inoculated during the 1st week or in 12 litters born to mothers inoculated during the 3rd week. The lack of evidence to substantiate viraemia or transplacental transmission in this model may explain in part the absence of malformations but virus and mouse strains were different to those used in previous reports.

A human maternal mortality rate of $27 \%$ was recorded during the 1918-19 influenza pandemic which increased to $50 \%$ when complicated by pneumonia (Harris, 1919). Although such a high mortality rate has not been observed since, pregnant women were found to be at greater risk than non-pregnant women during the 1957 pandemic, particularly women in their 3rd trimester (Greenberg, Jacobziner, Pakter \& Weisl, 1958; Freeman \& Barno, 1959; Widelock, Csizmas \& Klein, 1963). In this study, mice in the 3rd week also exhibited a highly significant increase in susceptibility to a lethal infection compared with mice in the 1st week or with non-pregnant mice. The reason for this increased susceptibility is unknown in mice, but is presently under investigation. In man, however, a depression in cell-mediated immunity has been observed during the 3rd trimester of pregnancy (Purtillo, 
Hallgren \& Yunis, 1972; Finn et al. 1972), which may be associated with increased susceptibility to viral infections.

Influenza infections during the 1st and 3rd weeks were found to exert a profound effect on neonatal development. Infections in the 3 rd week resulted in a significantly increased infant mortality during the first 8 weeks of life, and a similar trend was observed in mice born to mothers infected in the 1st week (Table 2). Growth rates of mice born to mothers infected during the last 3 days of the 1st week were also significantly reduced (Fig. 1) for their first 8 weeks. Increased neonatal mortality and reduced infant growth rates following influenza infections during pregnancy have not been reported in other murine studies, nor have they been observed in human infections. Reduced growth rates in mice, however, have been described in neonates from mothers infected during pregnancy with reovirus but, if killed, no virus or morphological lesions could be detected (Hashimi, Carruthers, Wolf \& Lerner, 1966). An increase in infant mortality was also described in the same report, but in all fatal cases reovirus was isolated from various infant tissues. Congenital infections with lymphocytic choriomeningitis virus may cause retarded growth rates, but the mice display a persistent tolerant infection throughout life (Mims, 1968). In the present study, the cause of infant mortality was not investigated, but in preliminary experiments, 6-week-old survivors from mothers infected with influenza during the 1 st and 3rd weeks did not have antibody to influenza and were equally susceptible to a lethal challenge infection as were the offspring from uninfected mothers (J.S. Mackenzie \& K. Williams, unpublished observations). Thus the mechanism by which influenza infections during pregnancy can influence neonatal development is unknown, but a persistent latent infection of the fetus without the induction of tolerance cannot be discounted, although evidence of viraemia and transplacental transmission was not obtained.

Finally, a murine system may provide a useful model for studying the potential risks which influenza infections during pregnancy may present to the mother, fetus and neonate. A number of parallels exist between the human situation and a murine model. They include the possession of three distinct tissue layers separating maternal and fetal blood; in other studies, the production of congenital malformations with influenza infections during the 1st week and transplacental transmission during the 3rd week; and an increased maternal mortality following infection in the 3rd week. In the latter instance, the pathological changes associated with fatal primary viral pneumonia in pregnant women in the 3rd trimester (Freeman \& Barno, 1959) are similar to the lung lesions observed in murine infections (Straub, 1937; Hers \& Mulder, 1961; G. Cambridge, J. S. Mackenzie, J.-M. Finlay-Jones, unpublished observations).

This work was supported by a research grant from the National Health and Medical Research Council. 


\section{REFERENCES}

Adams, J. M., Heath, H. D., Imagawa, D. T., Jones, M. H. \& Shear, H. H. (1956). Viral infections in the embryo. American Journal of Diseases of Children 92, 109-14.

Corfey, V. P. \& Jrssor, W. J. E. (1959). Maternal influenza and congenital deformities. A prospective study. Lancet ii, 935-8.

Finn, R., St Hill, C. A., Govan, A. J., Ralfs, I. G., Gurney, F. J. \& Denye, V. (1972). Immunological responses in pregnancy and survival of fetal homograft. British Medical Journal iii, 150-2.

Freeman, D. W. \& Barno, A. (1959). Deaths from Asian influenza associated with pregnancy. American Journal of Obstetrics and Gynecology 78, 1172-5.

Greenberg, M., JAcobziner, H., PAkTer, J. \& Weisl, B. A. G. (1958). Maternal mortality in the epidemic of Asian influenza, New York City, 1957. American Journal of Obstetrics and Gynecology 76, 897-902.

Hakosalo, J. \& SaXEN, L. (1971). Influenza epidemic and congenital defects. Lancet ii, 1346-7.

Hamburger, V. \& Haber, K. (1947). Teratogenic and lethal effects of influenza A and mumps viruses on early chick embryos. Proceedings of the Society for Experimental Biology and Medicine 66, 608-17.

HAMre, D., APPEL, J. \& LoosLI, C. G. (1955). Viraemia in mice with pulmonary influenza A virus infection. Journal of Laboratory and Clinical Medicine 47, 182-93.

Hashimi, A., Carruthers, M. M., Wolf, P. \& Lerner, A. M. (1966). Congenital infections with reovirus. Journal of Experimental Medicine 124, 33-46.

Harris, J. W. (1919). Influenza occurring in pregnant women. A statistical study of thirteen hundred and fifty cases. Journal of the American Medical Association 72, 978-80.

Heath, H. D., Sheiar, H. H., Imagawa, D. T., Jones, M. H. \& Adams, J. M. (1956). Teratogenic effects of Herpes simplex, vaccinia, influenza A (NWS), and distemper virus infections on early chick embryos. Proceedings of the Society for Experimental Biology and Medicine 92, 675-82.

HERS, J. F. P. \& MULDER, J. (1961). Broad aspects of the pathology and pathogenesis of human influenza. American Review of Respiratory Diseases 83, Supplement, 84-9.

Khakpour, M., SaIDI, A. \& Naficy, K. (1969). Proved viraemia in Asian influenza (Hong Kong variant) during incubation period. British Medical Journal iv, 208-9.

LECK, I. (1963). Incidence of malformations following influenza epidemics. British Journal of Preventive and Social Medicine 17, 70-80.

LECK, I. (1971). Further tests of the hypothesis that influenza in pregnancy causes malformations. HSMHA Health Reports 86, 265-9.

LECK, I., HAY, S., WITTE, J. J. \& GReENE, J. C. (1969). Malformations recorded on birth certificates following A2 influenza epidemics. Public Health Reports 84, 971-9.

LehmanN, N. I. \& Gust, I. D. (1971). Viraemia in influenza. A report of two cases. Medical Journal of Australia 2, 1166-9.

London, W. T., Fuccrllo, D. A., Sever, J. L. \& Kent, S. G. (1975). Influenza virus as a teratogen in rhesus monkeys. Nature, London 255, 483-4.

MACKEnzIE, J.S. \& Hodghton, M. (1974). Influenza infections during pregnancy: association with congenital malformations and with subsequent neoplasms in children, and potential hazards of live virus vaccines. Bacteriological Reviews 38, 356-70.

Mrms, C. A. (1968). Pathogenesis of viral infections of the fetus. Progress in Medical Virology 10, 194-237.

NAFicy, K. (1963). Human influenza infections with proved viraemia: report of a case. New England Journal of Medicine 269, 964-6.

Purtillo, D. T., Hallgren, H. M. \& Yunis, E. J. (1972). Depressed maternal lymphocyte response to phytohaemagglutinin in human pregnancy. Lancet i, 769-71.

Robertson, G. G., Wirliamson, A. P. \& Blattner, R. J. (1960). Origin of myeloschisis in chick embryos infected with influenza A virus. Yale Journal of Biology and Medicine 32, 449-63.

Seim, R. A., Ly, H., Imagawa, D. T. \& Adams, J. M. (1960). Influenza virus infections in pregnant mice. Journal of Neuropathology and Experimental Neurology 19, 125-9. 
StradB, M. (1937). The microscopical changes in the lungs of mice infected with influenza virus. Journal of Pathology and Bacteriology 45, 75-8.

Sweet, C., Toms, G. L., Kingsman, S. M. \& Smith, H. (1976). The pregnant ferret as a model for studying influenza virus infection in utero. Proceedings of the Society for General Micro. biology 3, 113-14.

WIDEloCK, D., Csizmas, L. \& KueIN, S. (1963). Influenza, pregnancy, and fetal outcome. Public Health Reports 78, 1-11.

Wrison, M. G. \& SteIN, A. M. (1969). Teratogenic effects of Asian influenza. Journal of the American Medical Association 171, 638-41.

Yawn, D. H., Pyeatte, J. C., Joseph, J. M., Eichler, S. L. \& Garcia-Bunued, R. (1971). Transplacental transfer of influenza virus. Journal of the American Medical Association 216, 1022-3. 